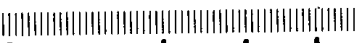

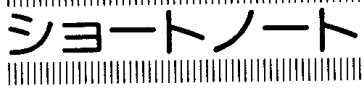

\title{
簡略化ファジ倠論によるコメの収量予測 ${ }^{\dagger}$
}

\section{竹澤 邦夫*}

\begin{abstract}
簡略化ファジィ推論は入出力関係を柔軟に表現する手段である。福島県で得られたデ一夕を用いて、気象デ 一夕を入力変数とし、単位面積あたりのコメの収量を出力变数とする簡略化ファジィ推論のルールを導出した ところ、従来の重回帰を用いた場合よりも高い予測精度を得ることができた。この結果を 1993 年のデー夕にあ てはめた結果、深刻な冷害が起こることを予想できた。

キーワード：簡略化ファジィ推論, クロス・バリデーション, 収量予測, ノンパラメトリック回帰
\end{abstract}

\section{1.はじめに}

1993 年の冷夏はコメの生産に重大な影響を及ぼし た。そのため、気象条件が農業生産に及ぼす影響が社 会的関心事となった。安定したコメの生産を行うため には気象条件がコメの生産に及ぼす影響を正しく理解 し、適切な対策を立てる必要があることが広く認識さ れるに至ったのである。幸い、日本には気象庁によっ て蓄積された気象デー夕と、農林水産省によって蓄え られたコメの収量に関するデータがあるので、それら を有效に利用すれば、気象条件がコメの生産に及ぼす 影響についての定量的な解析が可能になると思われる。 そこで、ファジイ推論の中で実用的に最も大きな成

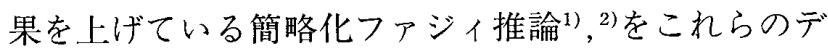
一夕に適用すれば、気象条件を用いてコメの生産を予 測したり、対策を立てたりすることが可能になること が期待できると考えた。これは、簡略化ファジイ推論 はファジイ推論の最も単純な形式でありながら多くの 事例においてより複雑な形式を用いた場合よりも優れ た結果を与えることが明らかになっているため、気象 条件を用いてコメの収量を予測するためにもふさわし いと思われるからである。また、気象条件とコメの生 産量との関係を因果関係に基づいて記述しようとする と、光合成、呼吸、蒸散などの要素が絡むため、数学 的な形式が複雑になりすぎて実用的ではなくなってし まう。この点も簡略化ファジィ推論が大きな成果を挙 げている制御の事例と共通している。更に、コメの生 産量を推定するにあたっては、それぞれのパラメータ の意味や統計的な性質よりも予測誤差が重要であるた め、パラメータの持つ数学的な性質より制御が与える

$\uparrow$ Prediction of Rice Yield by Simplified Fuzzy Logic

* Kunio TAKEZAWA

農林水産省北陸農業試験場研究技術情報科

Research Information Section, Hokuriku National Agricultural Experiment Station
快適さや適用範囲の広さを重視する場合に有効な簡略 ファジィ推論が効果的な手段と考えられる。

ここでは、福島県のデー夕に適用した事例を用いて、 実際のコメの生産量の予測に関して簡略化ファジィ推 論がどのように役立つかを示す。用いられるデー夕は、 入力変数がスカラーではなく、分布で表される点に特 徵がある。通常のファジイ推論においては入力変数が 曖昧さを伴っていることが多いが、ここでは数値デー 夕の分布を用いている。しかし、数学的な取り扱いは、 入力変数が曖昧さを伴う場合も分布の場合も本質的な 違いはない。

\section{2. 計算方法}

簡略化ファジィ推論においては以下のようなルール が用いられる。

if $X$ は $X_{1}^{*} に$ 近い then $Y=Y_{1}^{*}$

if $X$ は $X_{2}^{*}$ に近い then $Y=Y_{2}^{*}$

if $X$ は $X_{M}^{*}$ に近い then $Y=Y_{M}^{*}$

ここで $X$ が入力変数、 $Y$ が出力変数である。「 $X$ は $X_{j}^{*}$ に近い」は、ここでは以下のよjなメンバーシップ 関数で表す。

$$
\mu_{j}(X)=\exp \left(-a\left(X-X_{j}^{*}\right)^{2}\right)
$$

を用いる。 $a$ は正の定数である。式(2) はメンバーシッ プ関数として最もよく利用されているものであり、メ ンバーシップ関数としてどのような形のものを用いる かは結果に大きな影響を与えないことがこれまでの簡 略化ファジィ推論を用いた制御や推定の事例から分か っているので、ここでは式(2)だけを用いた。

$\left\{X_{j}^{*}\right\}(1 \leq j \leq M)$ を固定して、 $\left\{Y_{j}^{*}\right\}(1 \leq j \leq M)$ を求 めるには、以下の值を最小にする。 


$$
E_{1}=\sum_{i}\left(Y_{i}-\frac{1}{D} \sum_{k} \frac{\sum_{j} \mu_{j}\left(X_{i k}\right) Y_{j}^{*}}{\sum_{j} \mu_{j}\left(X_{i k}\right)}\right)^{2}
$$

を最小化する。ここで、 $\left\{\left(X_{i 1}, \cdots, X_{i k}, \cdots, X_{i D}, Y_{i}\right)\right\}(1$ $\leq i \leq N)$ がデータである。 $\left(X_{i 1}, \cdots, X_{i k}, \cdots, X_{i D}\right)$ が分 布で表された入力変数で、例えば、 $D$ ヶ月間の毎月の 平均気温である。 $Y_{i}$ は出力変数である。そして、 $\left(X_{1}^{+}\right.$, $\left.\cdots, X_{k}^{+}, \cdots, X_{D}^{+}\right)$に対する推定值 $\left(Y^{+}\right)$は、最適化された $\left\{Y_{j}^{*}\right\}$ を用いて、

$$
Y^{+}=\frac{1}{D} \sum_{k} \frac{\sum_{j} \mu_{j}\left(X_{k}^{+}\right) Y_{j}^{*}}{\sum_{j} \mu_{j}\left(X_{k}^{+}\right)}
$$

とする。

得られたルールの妥当性を調べるための統計量とし て、以下のよjなクロス・バリデーション $(C V)^{3)}$ を用 いる。

$$
C V=N^{-1} \sum_{i}\left(Y_{i}-Y_{i(i)}^{+}\right)^{2}
$$

ここで、 $Y_{i(i)}^{+}$は $i$ 番目のデー夕を除いて得られた入出 力関係を用いて推定した $i$ 番目の推定值である。この 基準を用いて簡略化ファジィ推論の形をしたルールを 求める。

ここで予測の妥当性を推定するために $C V$ を用い る理由は、 $C V$ を使えば様々な形式を持った予測式が 与える予測誤差を比較することができるため、幅広く 用いられている。特に、ここでは、実用的な観点に立 てば、気象条件を利用してコメの収量を予測するとい う実用的な要請に応えることを目的にしているので、 $C V$ の值を小さくする方法を優れた方法と考える。

この方法は容易に独立変数が 2 次元の場合に拡張で きる。そのときは、以下のようなルールを用いる。

if $X_{1}$ は $X_{11}^{*}$ に近く, $X_{2}$ は $X_{21}^{*}$ に近い then $Y=Y_{1}^{*}$ if $X_{1}$ は $X_{12}^{*}$ に近く, $X_{2}$ は $X_{22}^{*}$ に近い then $Y=Y_{2}^{*}$

if $X_{1}$ は $X_{1 M}^{*}$ に近く, $X_{2}$ は $X_{2 M}^{*}$ に近い then $Y=Y_{M}^{*}(6)$ そして、以下の值を最小にする。

$E_{2}=\sum_{i}\left\{Y_{i}-\frac{1}{D} \sum_{k} \frac{\sum_{j} \mu_{j}\left(X_{1 i k}, X_{2 i k}\right) Y_{j}^{*}}{\sum_{j} \mu_{j}\left(X_{1 i k}, X_{2 i k}\right)}\right\}^{2}$

ここで、\{( $X_{1 i 1}, \cdots, X_{1 i k}, \cdots, X_{1 i D}, X_{2 i 1}, \cdots, X_{2 i k}, \cdots$, $\left.\left.X_{2 i D}\right)\right\}(1 \leq i \leq N)$ がデータの入力変数、 $\left\{Y_{i}\right\}(1 \leq i \leq$ $N)$ がデー夕の出力変数である。 $\left\{\left(X_{1 j}^{*}, X_{2 j}^{*}\right)\right\}(1 \leq j \leq$ $M)$ と $\left\{Y_{j}^{*}\right\}(1 \leq j \leq M)$ がメンバーシップ関数を決め るパラメータで、「if $X_{1}$ は $X_{1 j}^{*} に$ 近く、 $X_{2}$ は $X_{2 j}^{*}$ に近い」 を表すメンバーシップ関数として、ここでは以下のも
のを用いる。

$$
\mu_{j}\left(X_{1}, X_{2}\right)=\exp \left(-a_{1}\left(X_{1}-X_{1, j}^{*}\right)^{2}-a_{2}\left(X_{2}-X_{2 j}^{*}\right)^{2}\right)
$$

ここで、 $a_{1}$ と $a_{2}$ は定数である。そして、 $\left(X_{11}^{+}, \cdots, X_{1 k}^{+}\right.$, $\left.\cdots, X_{1}^{+}, X_{21}^{+}, \cdots, X_{2 k}^{+}, \cdots, X_{2 D}^{+}\right)$に対する推定値 $\left(Y^{+}\right)$は、最適化された $\left\{Y_{j}^{*}\right\}$ を用いて、

$$
Y^{+}=\frac{1}{D} \sum_{k} \frac{\sum_{j} \mu_{j}\left(X_{1 k}^{+}, X_{2 k}^{+}\right) Y_{j}^{*}}{\sum_{j} \mu_{j}\left(X_{1 k}^{+}, X_{2 k}^{+}\right)}
$$

とする。

\section{3. 福島県のデータを事例とする応用例}

気象デー夕は 1979 年から 1992 年までの間に福島市 ๑ AmeDAS (Automated Meteorological Data Aquisitin System) 観測点で測定されたもののうち、7 月から 9 月の毎月の平均気温 $\left({ }^{\circ} \mathrm{C}\right)$ と月ごとの日平均日 照時間 (hours/day)を用いた。コメの収量 $(\mathrm{kg} / 10 \mathrm{a})$ は 農林水産省が発表したデータである。

まず、古典的な重回帰を用いた回帰を試みた。用い たソフトウエアはPC 98 の上で動作する SPSS/PC Ver.2.0の日本語版である。このソフトウエアを用い て、3ヶ月間の月ごとの平均気温と平均日照時間の、合 わせて $6 つ$ つ独立変数の候補とし、目的变数はコメの 収量としてステップワイズ法を用いた変数選択を行っ て、得られた重回帰式は以下のものである。

$$
Y=T_{7} \times 18.6+T_{8} \times 15.6+T_{9} \times 22.1-782.9(10)
$$
ここで、 $T_{7} 、 T_{8} 、 T_{9}$ はそれぞれ 7,8,9 月の平均気温で ある。日照時間は全く選択されなかった。クロスバリ デーションを用いて推定して得られた、(9)が与える予

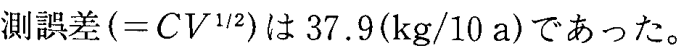

ただし、この $C V$ は独立変数が変数が $T_{7} 、 T_{8} 、 T_{9}$ に 固定して得られたものなので、変数選択が $C V$ の值に 及ぼす影響は考慮していない。図1はクロス・バリデ ーションを用いて得られた予测值 ((5)の $Y_{i(i)}^{+}$と、実測 值である。

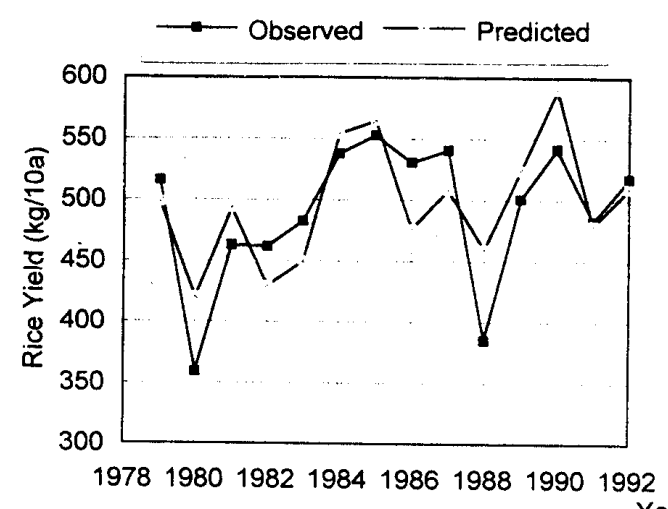

図1 従来の重回帰を用いたコメの収量の予測 (“Observed”は観測值、“Predicted”は式(5)の $Y_{i(i)}^{*}$ ) 
次に、簡略化ファジイ推論を用いて独立变数として 3 ヶ月間の月平均気温を分布として用いた場合と、さ らに 3 ヶ月間の月平均日射量の分布を加えて 2 つの独 立变数を用いて計算を行った。すなわち、(4)と（7）に おける $D$ は 3 である。

3 ヶ月間の月平均気温を用いた計算の結果、四 2 の ようなノンパラメトリックな回帰曲線が得られた。こ のとき、 $M=3 、(2) に$ におる $a=1 / 25 、\left\{X_{j}^{*}\right\}=\{15.0$ ， $22.5,30.0\}$ とした。この $\left\{X_{j}^{*}\right\}$ は

$$
\begin{gathered}
X_{j}^{*}=15.0+15.0 \cdot(j-1) /(M-1) \\
(1 \leq j \leq M)
\end{gathered}
$$

として $M$ を最適化した結果、得られたものである(図 3)。このときの予測誤差 $\left(=C V^{1 / 2}\right)$ は $27.0(\mathrm{~kg} / 10 \mathrm{a})$ と なり、先の重回帰を使った場合に比べて、かなり改善 されたことが分かる。次に、月平均気温と月平均日照 時間を使った計算を行ったところ予測誤差 $\left(=C V^{1 / 2}\right)$ は $25.1(\mathrm{~kg} / 10 \mathrm{a})$ となり、月平均気温だけを用いた場 合よりもさらに優れた結果となった。このときの入出 力関係は図 4 で、 $\left.\left\{\left(X_{1 i}^{*}, X_{2 i}^{*}\right)\right\}(1 \leq i \leq 4)\right)$ は $(0,0)$ 、 $(0,30) 、(10,0) 、(10,30) 、(8)$ における $a_{1}=1 / 100 、 a_{2}=$ 4/900である。この $\left(\left\{\left(X_{1 i}^{*}, X_{2 i}^{*}\right)\right\}\right.$ は、いくつかの值の 組合せを試みた結果、最も $C V$ の值が小さくなるもの を選んだものである。図 4 は日照時間が増大しても必 ずしもコメの収量は増大しないことを示している。し かし、最小二乗法によって得られた入出力関係は必ず

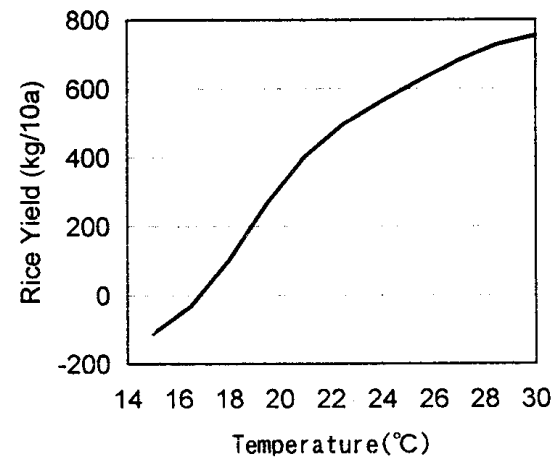

図2 月平均気温を唯一の入力変数とする簡略化 ファジィ推論のルールによる入出力関係

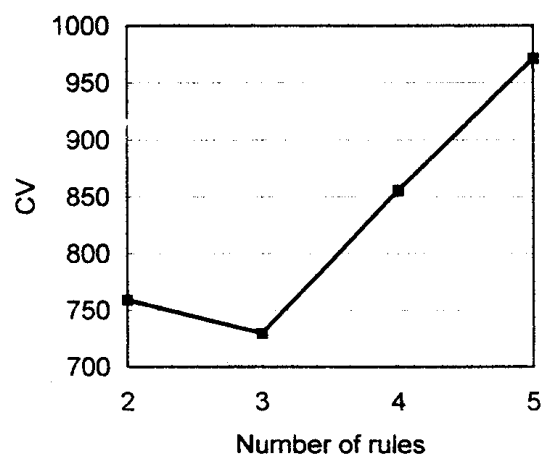

図3 月平均気温を唯一の入力变数とする簡略化 ファジィ推論のルールを求めるにあたって の、CVによるルールの数の最適化
しも因果関係を示しているわけではないので、あくま でも予測のために役に立つ入出力関係が得られたこと に重点を置いて理解すべきだろう。実際、この計算に おいてクロスバリデーションを使って得られた予測值 を実測値と合わせて示した図 5 は予測值が実測值にか なり近い値をとっていることを示している。図 1 と図 5 と比べると、収量が平年值からかなり離れている、 1980 年、1988 年、1990 年において予測精度の向上が著 しいことが分かる。つまり、簡略化ファジィ推論を用 いた場合は、ルールの数とそのパラメータの值の決定 にいくらかの試行錯誤を必要とするものの、古典的な 重回帰を行った場合に比べて実用性の高い予測が可能 になったのである。簡略化ファジィ推論におけるルー ルの選択やパラメータの決定にあたっては遺伝的アル ゴリズムなどを用いた自動化が可能になると思われる ので、試行錯誤の手間は徐々に派減されてゆくことが 期待できる。

このように、福島県に扮けるコメの収量予测に簡略 化ファジイ推論が有効であることが分かったので、 1993 年の 9 月の始めに気象デー夕を使った収量予測 を試みた。この年は夏期の低温と長雨による冷害が心

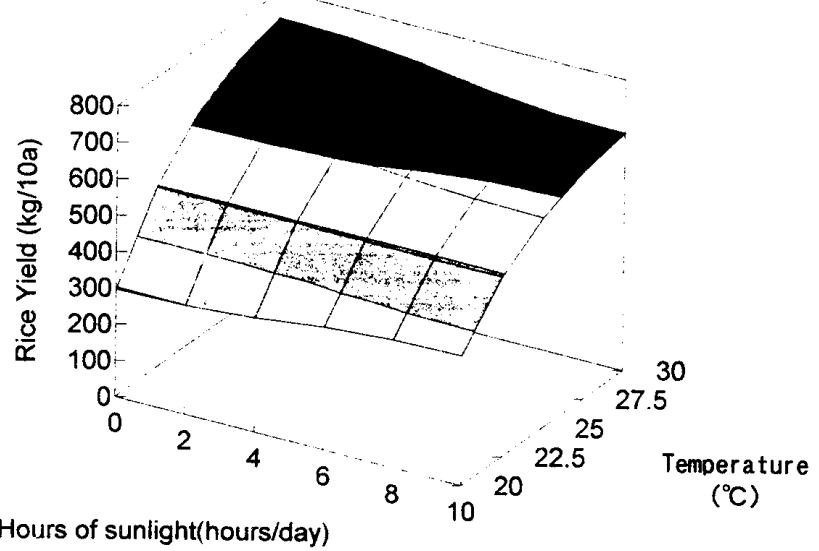

図4 月平均気温と月平均日照時間を入力変数と する簡略化ファジィ推論による入出力関係

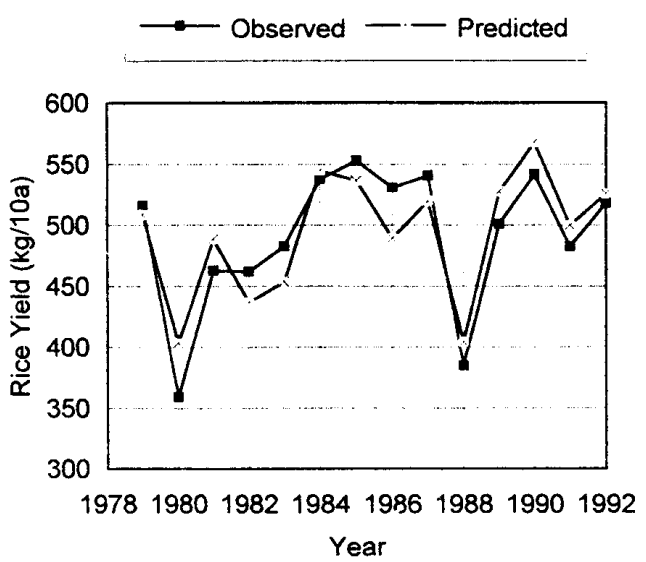

図5 図4に示されている入出力関係を用いた コメの収量の予測

(“Observed”は観測值、“Predicted”は式(5)の $Y_{i(i)}^{*}$ ) 
配されたので、実際の収量がどのような值になり、そ れに対してどのような対策をとればよいかが広い関心 を集めていた。9月の始めの時点では 9 月の気象デー 夕は利用できないので、 9 月の日照時間は 1979 年から 1992 年までの平均に等しいと仮定し、気温に関しては 以下の 4 つの仮定を置いた。 $(\mathrm{A})$ 平年並み、(B) 平年よ り 1 度低い、(C) 平年より 2 度低い，(D) 平年より 3 度 低い、という 4 つである。この年は近年にない低温で あったので、 9 月の気温は平年より 2 度低いという仮 定を採用し、図 4 に示されている曲面を使って、325.4 $\mathrm{kg} / 10 \mathrm{a}$ という值を得た。一方、式(10)を用いた場合は $351.5 \mathrm{~kg} / 10 \mathrm{a}$ となった。

10 月 15 日に農林水産省から発表された 1993 年に おける最終的なコメの収量は、福島県に扔いては 328 $\mathrm{ka} / 10 \mathrm{a}$ (図 6 の $\mathrm{E}$ ) であった。この年の気象条件が特異 なものであったことを考えると、 $325.4 \mathrm{~kg} / 10 \mathrm{a}$ という 予測值は極めて高い精度のものであったと言える。し かし、気象庁から発表された 9 月の福島県における観 測結果は、月平均日照時間は 1979 年から 1992 年の平 均より 3.2 時間短く、気温は同じ時期の平均上り 1.1 度低い、というものであった。9月は雨が多く、日照時 間はかなり短くなったが気温の低下は小幅に止まった のである。この観測結果を図 4の入出力関係にあては めると、373.4 kg/10a(図 6 の F) という值が得られ た。つまり、もし 9 月の気象条件が正確に予測できて いたとすると、収量の予測值は実際よりいくらか大き な值となってしまっていたのである。一方、式(10)を 用いた場合は $371.4 \mathrm{ka} / 10 \mathrm{a}$ となり、簡略化ファジィ 推論との優劣ははっきりしなかった。しかし、いずれ の方法を用いた場合でも、この年の福島県におけるコ メの収量は少なくとも $400 \mathrm{~kg} / 10 \mathrm{a}$ 以下という深刻な ものであることが 9 月始めの時点で明らかになったこ との意義は大きい。

\section{4. おわりに}

気象条件が農業生産に与える影響を予測することを 目的として多くの方法が試みられてきた。回帰分析は コメなどの生産量を予測するための手法の代表的なも のである。しかし、従来の重回帰分析を用いた場合は 十分な予測精度が得られないことも多かった。そのた め、予測精度の向上のためには植物の内部のメカニズ ムを考慮したモデルを導入しなければならないという 考えもあった。しかし、ファジィ推論やノンパラメト リック回帰が飛躍的に進歩した結果、状況は変わった。 従来の重回帰を用いても十分な予測精度が得られない とされてきたデー夕をこれらのより柔軟性と実用性の 高い手法を用いて再検討すれば実用的な予测精度が得

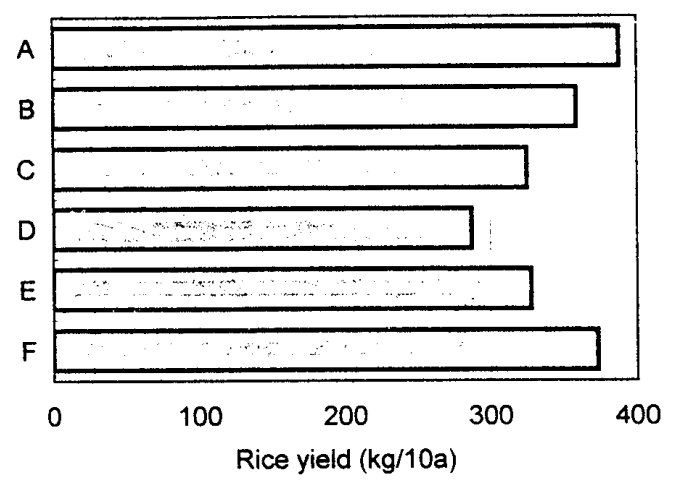

A：1993年の9月の平均気温が1978年から1992年の9月の平均気 温と等しいと仮定して、図4の入出力関係によって得られた 予测収量

B：1993年の9月の平均気温が1978年から1992年の9月の平均気 温より $1^{\circ} \mathrm{C}$ 低いと仮定して、図4の入出力関係によって得ら れた子測収量

C：1993年の9月の平均気温が1978年から1992年の9月の平均気 温より $2^{\circ} \mathrm{C}$ 低いと仮定して、図 4 の入出力関係によって得ら れた予測収量

D：1993年の9月の平均気温が1978年から1992年の9月の平均気 温より $3^{\circ} \mathrm{C}$ 低いと仮定して、図4の入出力関係によって得ら れた予測收量

$\mathrm{E} ：$ 1993年における害際の収量

F：1993年に㧍ける実際の気象データを四4の入出力関係に代入 して得られた予測収量

図6 1993年9月の初頭における福島のコメの収量 の予測、実際の収量、穾際の気象デー夕を 図4に示されている入出力関係に代入して 得られた収量

られる可能性が出てきたのである。特に簡略化ファジ イ推論については、最近、generalized reguralization networks と称して、簡略化ファジイ推論、ノンパラメ トリック回帰、ニューラル・ネットワークを統合する 理論体系の構築が行われている4)。そのため、簡略化フ アジィ推論の重要性は理論的な面でもいっそう強調さ れるようになってきた。

しかし、こうした手法を用いて得られた回帰式モデ ルを予測に用いる場合には、予測に用いるときの独立 変数の变域や変数間の相関構造などが、回帰式を作る ために用いたデータとほぼ同じであることを確認して おく必要がある5)。また、簡略化ファジイ推論を使いさ えすれば従来の方法よりも優れた結果が得られるとは 限らない。単純な直線回帰の方が複雑な曲面を用いた 回帰よりも優れた結果を与えることもあり得る。デー 夕から自動的に回帰式やモデルを導くための様々な努 力は大きな成果をあげているとはいえ、データさえ用 意すれば、すべての手続きが自動的に行われるアルゴ リズムを生み出すまでには至っていないのである。 


\section{参 考 文 献}

(1) 花見・洔井：ファジイ理諭の家電への応月、ファジイ 技術の尖湖化技術，シュプリンガー・フェアラーグ社， pp.255-277, 1992

(1995年 6 月 $17 \mathrm{H}$ 再受付)

(2) 竹澤：ノンパラメトリック回帰からみたファジィ推論, 日本ファジィ学会誌, Vol.5, No.6, pp.1273-1279, 1993.

(3)竹澤：続・ノンパラメトリック回州からみたファジィ 推論, 日本ファジィ学会誌, Vol.7, No.1, pp.35-43, 1995.

(4) F. Girosi, M. Jones and T. Poggio: Regularization [間い命わせ先]

干943-01 新鼬坚上越市稻 $141-2-1$ 農林水産省北陸農業試験埸 研究技術情報科

竹澤 邦夫

TEL : 0255-26-3214

FAX : 0255-24-8578

E-mail:takezawa@inada.affrc.go.jp Theory and Neural Networks Architectures, Neural Computation, 7, pp.219-269, 1995

(5) 久米，飯塚：问州分析，岩波軘店，1987.

\section{著 者 紹 介}

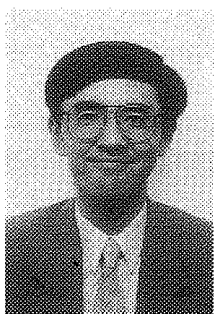

竹澤 邦夫（たけされくに施）

農林水産省 北陸農業娬駼場 研究技術情 報科

1984年 多古屋大学大学院上学研究科 㐫用物理学:尃攻前期裸程修了。[间年上り， 1995年3月まで, 農林水産省 農業環境技 術研究所に勤務し、ノンパラメトリック

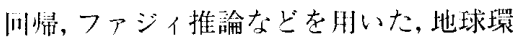
境, 氞象, 農業生産などの解析とモデル化 の研究に従事。1995年4月より現職。川本

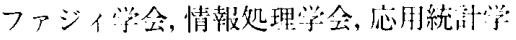

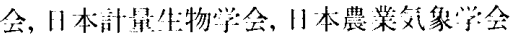
などの会り。

\section{Prediction of Rice Yield by Simplified Fuzzy logic \\ by Kunio TAKEZAWA}

\section{Abstract :}

Simplified fuzzy logic permits flexible representation of input-output relationships. In this study, sets of fuzzy rules based on simplified fuzzy logic were derived from observed data in the Fukushima area; meteorological data were input and rice yield data was output. These sets of rules outperformed a conventional multiple linear equation. Application of those rules to the observed meteorological data in 1993 predicts serious cold-weather damage of the year.

Keywords : Cross-Validation, Nonparametric Regression, Simplified Fuzzy Logic, Yield Prediction

\section{Contact Address : Kunio TAKEZAWA}

Research Information Section,

Hokuriku National Agricultural Experiment Station

Inada 1-2-1, Jyoetu, Niigata 934-01, Japan

TEL : 0255-26-3214

FAX : 0255-24-8578

E-Mail : takezawa@inada.affrc.go.jp 